CLINICAL STUDY

\title{
Calcitonin screening and pentagastrin testing: predictive value for the diagnosis of medullary carcinoma in nodular thyroid disease
}

\author{
B L Herrmann ${ }^{1,2}$, K W Schmid ${ }^{3}$, R Goerges ${ }^{4}$, M Kemen $^{5}$ and K Mann ${ }^{1}$ \\ ${ }^{1}$ Department of Endocrinology and Division of Laboratory Research, University Duisburg-Essen, Essen, Germany, ${ }^{2}$ Division of Endocrinology, Diabetology \\ and Laboratory, Technology Center Bochum, Universitätsstraße 142, D-44799 Bochum, Germany, Departments of ${ }^{3}$ Pathology and Neuropathology and \\ ${ }^{4}$ Nuclear Medicine, University Duisburg-Essen, Essen, Germany and ${ }^{5}$ Department of Visceral Surgery, Ev. Hospital Herne, Herne, Germany \\ (Correspondence should be addressed to B L Herrmann at Division of Endocrinology, Diabetology and Laboratory, Technology Center Bochum; \\ Email: herrmann@endokrinologie-tzr.de)
}

\begin{abstract}
Context: Serum calcitonin (hCT) measurement may be useful for detecting medullary thyroid carcinoma (MTC), but the routine use of hCT after pentagastrin stimulation to screen patients with nodular thyroid disease remains controversial.

Patients: A total of 1007 patients (567 females and 440 males) with nodular thyroid disease and a mean age of $55 \pm 14$ (mean \pm s.D.) years were included in the study. All patients did not have impaired renal function, bacterial infection, alcohol and drug abuse, pseudohypoparathyroidism, or protonpump inhibitor therapy. Individuals referred with known elevation of hCT, Graves' disease, or autoimmune thyroid disease were not considered or included in this investigation.

Methods: Serum hCT levels were determined under basal conditions, and when basal values were $\geq 10$ and $<100 \mathrm{pg} / \mathrm{ml}$, testing was repeated after pentagastrin stimulation. Patients with basal or stimulated levels $>100 \mathrm{pg} / \mathrm{ml}$ were referred for surgery.

Results: hCT levels $>10 \mathrm{pg} / \mathrm{ml}$ were increased in 17 patients $(1.7 \%)$. One patient had a basal hCT level of $4400 \mathrm{pg} / \mathrm{ml}$ with a histological confirmation of a MTC. In this patient, pentagastrin test was not performed. Sixteen patients with basal hCT between 10 and $100 \mathrm{pg} / \mathrm{ml}$ underwent pentagastrinstimulated hCT measurement. Of 16 patients, 4 had stimulated hCT $>100 \mathrm{pg} / \mathrm{ml}$. Of 17 patients with $\mathrm{hCT}>10 \mathrm{pg} / \mathrm{ml}, 2$ had MTC, and of 17 patients, 3 had C-cell hyperplasia. In total, two patients $(0.20 \%)$ had a histologically verified MTC.

Conclusions: Basal hCT measurement together with pentagastrin-stimulated hCT measurement in cases of basal hCT $>10 \mathrm{pg} / \mathrm{ml}$ detects MTC in $0.20 \%$ of patients with nodular thyroid disease. Whether this high incidence of MTC has major implications or not has to be discussed, but it should be considered as a useful and recommended tool for early detection of MTC and to save patients' life.
\end{abstract}

European Journal of Endocrinology 162 1141-1145

\section{Introduction}

In Germany, thyroid nodules are frequently observed in clinical practice with a prevalence of about $23 \%$ (1). Calcitonin (CT) is a 32-amino acid polypeptide secreted mainly by the parafollicular C-cells of the thyroid, and medullary thyroid carcinomas (MTCs) are derived from the same cells, and they uniformly express CT (2). MTC reportedly accounts for $\sim 5 \%$ of all the thyroid carcinomas, and is sporadic in $50-78 \%$ of the cases (3-7). MTC is characterized by early micrometastasis and a lack of curative non-surgical treatment, so that early diagnosis is desirable. By the time patients with MTC present with clinical disease, the condition is usually metastatic and cannot be cured by surgery.
An elevated serum calcitonin (hCT) value in patients with thyroid nodules after exclusion of potential conditions (impaired renal function, bacterial infection, alcohol and drug abuse, pseudohypoparathyroidism, or proton-pump inhibitor therapy) needs re-testing after an i.v. pentagastrin administration. HCT, stored in dense-cored secretory granules, can be released into the bloodstream with the synthetic analog gastrin pentapeptide (pentagastrin) (8). Pentagastrin binds to the extracellular domain of the transmembrane cholecystokinin-B/gastrin receptor, and stimulates hCT secretion (9). Therefore, hCT measurements after pentagastrin testing are used for biochemical diagnosis of primary and/or occult MTCs.

In spite of the fact that many European consensus groups and societies recommended hCT measurement 
as the screening parameter that detects medullary thyroid cancer, the majority of the physicians do not routinely use this test $(10,11)$. In the last few years, several studies revealed different upper limits of basal hCT values to detect MTC and to reduce false-positive cases (12-15). The present study sheds further light on the hCT measurement and its testing after pentagastrin stimulation in patients with thyroid nodule disease.

\section{Patients and methods}

A total of 1007 patients (567 females and 440 males, mean age of $55 \pm 14$ years, median 56 years) with nodular thyroid disease found by sonography living in central Germany, an area with endemic goiter due to previous iodine deficiency, were included in the study between June 2005 and September 2009. In one single center (Division of Endocrinology, Technology Center Bochum, Germany), patients with known or unknown thyroid disease underwent ultrasound. In the case of thyroid nodules, measurement of hCT was done, and it was the first hCT determination in every patient. Individuals referred with known elevation of hCT, Graves' disease, or autoimmune thyroid disease were not considered or included in this investigation.

All patients did not have impaired renal function, bacterial infection, alcohol and drug abuse, pseudohypoparathyroidism, or proton-pump inhibitor therapy. hCT was measured at the Institution of Endocrinology and Laboratory in the Technology Center of Bochum, Germany, using the solid-phase, enzyme-labeled, two-site chemiluminescent assay with the Immulite 2000 (Siemens Immulite 2000, Munich, Germany). When basal CT values were $\geq 10$ and $<100 \mathrm{pg} / \mathrm{ml}$, testing was repeated 2 and 5 min after pentagastrin stimulation (with an i.v. bolus injection of $0.5 \mu \mathrm{g}$ pentagastrin (Peptavlon; Laboratoires SERB, Paris, France) per kilogram body weight) at the same institution. Basal or stimulated levels $>100 \mathrm{pg} / \mathrm{ml}$ were referred for surgery.

In the case of patients with elevated pentagastrinstimulated hCT levels $>100 \mathrm{pg} / \mathrm{dl}$ or basal hCT $>$ $100 \mathrm{pg} / \mathrm{dl}$, total thyroidectomy was performed. Moreover, both recurrent nerves were dissected carefully, and a systemic microdissection of the central lymph node compartments along both the nerves from the upper thoracic outlet up to the larynx was done. Germline mutations of the RET proto-oncogene were investigated in all the patients with MTC.

All patients had given informed consent to the diagnostic and therapeutic procedures. For retrospective analysis of the existing datasets from routine patient care, no institutional review board approval is required under the German law and applicable institutional regulations.

\section{Results}

hCT levels $>10 \mathrm{pg} / \mathrm{ml}$ were increased in 17 patients (1.7\%; Fig. 1). One patient had a basal hCT level of $4400 \mathrm{pg} / \mathrm{ml}$ with a histological confirmation of a MTC (Table 1). In this patient, pentagastrin test was not performed. Sixteen patients with basal hCT between 10 and $100 \mathrm{pg} / \mathrm{ml}$ underwent pentagastrin-stimulated hCT measurement (Fig. 2). The mean increase of hCT after pentagastrin stimulation (Table 1) was 4.6-fold (range 2.6-7.9) in patients $1-12,8.8$-fold (range 8.5-8.8) in patients 13-15 (C-cell hyperplasia, $\mathrm{CCH}$ ), and 25-fold in patient 16 (MTC).

All patients with basal or stimulated hCT $>$ $100 \mathrm{pg} / \mathrm{ml}$ could be observed for follow-up, and they underwent total thyroidectomy as well as the systemic microdissection of the defined regions. No permanent paralysis of the recurrent nerves was observed. One patient had permanent hypoparathyroidism. Of 17 patients, 5 had basal/stimulated hCT $>$ $100 \mathrm{pg} / \mathrm{ml}, 2$ had MTC, and 3 had CCH. In total, two patients $(0.20 \%)$ had histologically verified MTC. No mutation of the RET proto-oncogene could be detected, so that the two MTCs were classified as sporadic $(16,17)$.

The age of the males with MTC was 76 years and that of the females was 66 years. Basal hCT levels of the patients were 58 and $4400 \mathrm{pg} / \mathrm{ml}$. Postoperative basal hCTs of the patients with $\mathrm{CCH}$ were $<2 \mathrm{pg} / \mathrm{ml}$, and those of patients with MTC were 2 and $11 \mathrm{pg} / \mathrm{ml}$ (Table 1). In the last patient (no. 16), stimulated hCT after pentagastrin testing increased to $200 \mathrm{pg} / \mathrm{ml}$. In patient no. 17 with preoperative basal hCT of $4400 \mathrm{pg} / \mathrm{ml}$, postoperative pentagastrin-stimulated hCT was $21 \mathrm{pg} / \mathrm{ml}$. Tumor size of patient no. 16 was $3 \mathrm{~mm}$ and of patient no. 17 with MTC was $20 \mathrm{~mm}$. The five patients with $\mathrm{CCH}$ and MTC were diagnosed by

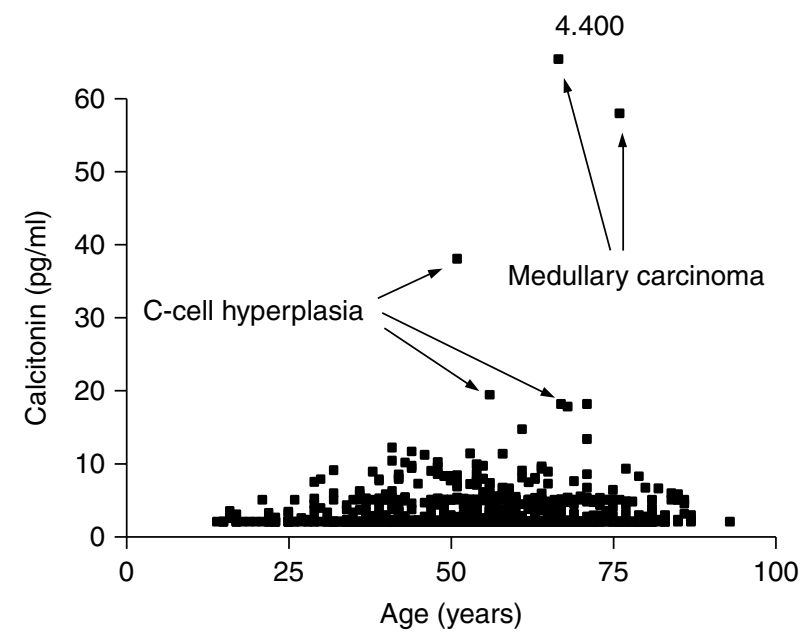

Figure 1 Serum calcitonin levels under basal conditions in 1007 patients with nodular thyroid disease. 
Table 1 Characteristics of patients with elevated serum calcitonin ( $\mathrm{hCT} ;>10 \mathrm{pg} / \mathrm{dl})$.

\begin{tabular}{|c|c|c|c|c|c|c|c|c|c|}
\hline No. & Age & $\operatorname{Sex}(M / F)$ & hCTb & hCTs & Sono & FNAB & Histology & Staging & hCTpost \\
\hline 1 & 43 & $M$ & 10.1 & 27 & 7 & Not done & & & \\
\hline 2 & 48 & $M$ & 10.2 & 33 & 18 & Not done & & & \\
\hline 3 & 41 & $\mathrm{M}$ & 10.4 & 45 & 14 & Not done & & & \\
\hline 4 & 46 & $\mathrm{M}$ & 11 & 29 & 9 & Not done & & & \\
\hline 5 & 58 & $\mathrm{M}$ & 11 & 66 & 11 & Not done & & & \\
\hline 6 & 53 & $\mathrm{M}$ & 11 & 83 & 9 & Not done & & & \\
\hline 7 & 44 & $\mathrm{M}$ & 12 & 35 & 5 & Not done & & & \\
\hline 8 & 41 & $\mathrm{M}$ & 12 & 95 & 8 & Not done & & & \\
\hline 9 & 71 & $\mathrm{M}$ & 13 & 99 & 30 & Not done & & & \\
\hline 10 & 61 & $\mathrm{M}$ & 15 & 39 & 9 & Not done & & & \\
\hline 11 & 68 & $\mathrm{M}$ & 18 & 64 & 25 & Not done & & & \\
\hline 12 & 67 & $\mathrm{M}$ & 18 & 73 & 8 & Not done & & & \\
\hline 13 & 71 & $\mathrm{M}$ & 18 & 160 & 17 & Not done & $\mathrm{CCH}$ & & $<2$ \\
\hline 14 & 56 & $\mathrm{M}$ & 19 & 176 & 28 & Negative & $\mathrm{CCH}$ & & $<2$ \\
\hline 15 & 51 & $\mathrm{M}$ & 38 & 322 & 10 & Not done & $\mathrm{CCH}$ & & $<2$ \\
\hline 16 & 76 & $\mathrm{M}$ & 58 & 1471 & 8 & MTC & MTC & pT3, M0, N1 & 11 \\
\hline 17 & 66 & $\mathrm{~F}$ & 4400 & Not done & 30 & Not done & MTC & pT2, MO, NO & 2 \\
\hline
\end{tabular}

Age (years). M, male; F, female; hCTb, basal hCT (pg/ml); hCTs, maximal pentagastrin-stimulated hCT (pg/ml); Sono, size of the dominant nodule by sonography (mm); FNAB, fine-needle aspiration; $\mathrm{CCH}$, C-cell hyperplasia; hCTpost, postoperative hCT (pg/ml).

histology by two different pathologists and were verified by a third pathologist, who had observed tissues from all the five patients.

To date, positron emission tomography investigation using fluorodeoxyglucose as the most sensitive and specific single modality could not detect metastases in this patient (18). Patients with stimulated $\mathrm{hCT}<100 \mathrm{pg} / \mathrm{ml}$ did not undergo surgery of the thyroid, and were under follow-up with re-testing.

\section{Discussion}

The present study has shown that hCT screening reveals one case of MTC among 500 patients with thyroid nodule disease. The present MTC prevalence of $0.20 \%$ in patients with thyroid nodule disease is lower, but it is also similar to that reported in some previous studies $(0.33-0.40 \%)$, in which patients with known hypercalcitonemia were excluded $(13,19,20)$. A higher prevalence rate has been reported in several previous studies, which may be due to patient selection and/or to different normal range values employed, which were determined by RIA or IRMA $(14,21-23)$. Vierhapper et al. have shown that before hCT screening was instituted, the diagnosis of MTC was made in 1 of 900 patients with thyroid nodule disease referred to their clinic (13). The determination of basal hCT was responsible for the threefold increase in diagnosing MTC. Moreover, the increase in the quality of ultrasonography is pivotal for the outcome of an hCT screening program as long as hCT is only determined in patients with thyroid nodule disease.

The cutoff level of hCT to initiate pentagastrin testing remains controversial, because basal hCT values between 10 and 100 represent a gray zone where true- and false-positive cases overlap (12, 22, 24-26).
We have performed pentagastrin testing in all patients with $\mathrm{hCT}>10 \mathrm{pg} / \mathrm{ml}$ without losing any of these patients to follow-up. Of 16 patients, 4 had $\mathrm{hCT}>$ $100 \mathrm{pg} / \mathrm{ml}$ after pentagastrin stimulation and underwent thyroidectomy, resulting in one MTC and two CCHs. In a recent study by Rink et al. the increase of the upper limit for basal hCT to $15 \mathrm{pg} / \mathrm{ml}$, instead of to $10 \mathrm{pg} / \mathrm{ml}$, significantly reduced the number of falsepositive cases (12). None of these patients with basal $\mathrm{hCT}<10 \mathrm{pg} / \mathrm{dl}$ had MTC. In our study, all patients with basal hCT $>15 \mathrm{pg} / \mathrm{ml}$ and pentagastrin-stimulated $\mathrm{hCT}>100 \mathrm{pg} / \mathrm{ml}$ had confirmed $\mathrm{CCH}$ or MTC. On the other hand, in another study by Vierhapper et al. basal $\mathrm{hCT}<15 \mathrm{pg} / \mathrm{dl}$ was stimulated by pentagastrin $>100 \mathrm{pg} / \mathrm{dl}$ with histological confirmation of MTC in one patient (13). Moreover, in the study by Rink et al. one patient had basal hCT $>15 \mathrm{pg} / \mathrm{ml}$ and

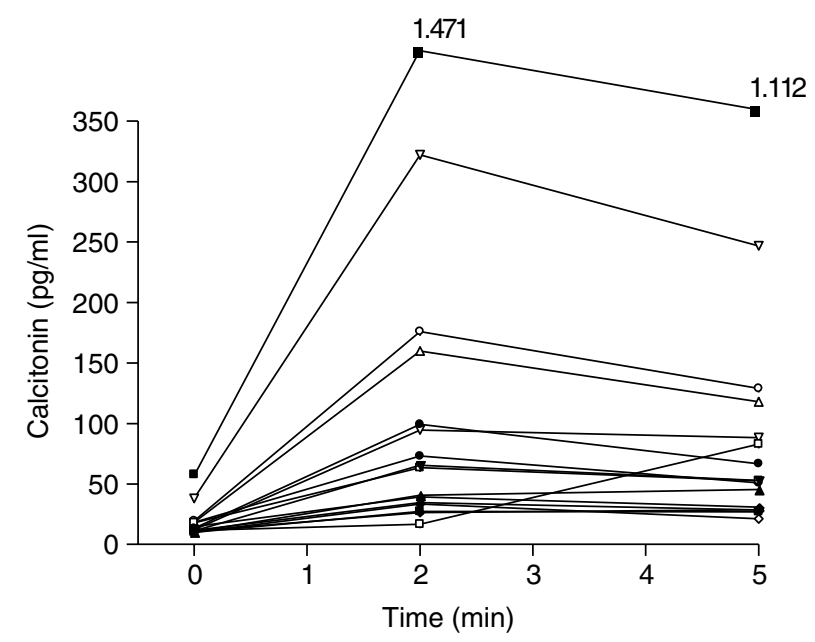

Figure 2 Calcitonin levels with pentagastrin testing in 16 patients with initial basal calcitonin values $>10$ and $<100 \mathrm{pg} / \mathrm{ml}$. 
pentagastrin-stimulated $\mathrm{hCT}$ of $81 \mathrm{pg} / \mathrm{dl}$ with histologically confirmed MTC, so that the cutoff levels of pentagastrin-stimulated $\mathrm{hCT}>100 \mathrm{pg} / \mathrm{dl}$ did not have $100 \%$ sensitivity (12). Moreover, stimulated hCT $>$ $100 \mathrm{pg} / \mathrm{ml}$ cannot differentiate between $\mathrm{CCH}$ and MTC, considering the histological results with $\mathrm{CCH}$ of three of our patients with stimulated hCT between 176 and $322 \mathrm{pg} / \mathrm{ml}$.

In a recent study by Doyle et al. stimulated hCT after the administration of high-dose calcium in comparison to that after the administration of pentagastrin was investigated. Calcium seemed to be a more potent and better tolerated hCT stimulator than pentagastrin, and it can be considered as a new and valid alternative in future (27).

Moreover, men and women differ in thyroid C-cell mass and CT secretion. To increase the positive predictive value, the existence of a gender-specific threshold predicting sporadic occult MTC (28) has to be discussed and considered.

Nevertheless, the risk of MTC is obviously very low in the range of $10-15 \mathrm{pg} / \mathrm{dl}$ of basal $\mathrm{hCT}$ and $\mathrm{hCT}<100 \mathrm{pg} / \mathrm{dl}$ after pentagastrin stimulation. This is in accordance with the upper limit of the normal range of $100 \mathrm{pg} / \mathrm{dl}$, as published in the German consensus recommendation of 2004 (10). The recommended yearly follow-up investigations in patients with pentagastrin stimulation of hCT between 50 and $100 \mathrm{pg} / \mathrm{dl}$ can shed new light on this issue. Lowering of this threshold for surgery may lead to the referral of many patients to unnecessary operations. Thus, the definition of $100 \mathrm{pg} / \mathrm{dl}$ as a therapeutic threshold reflects a clinical compromise, balancing overtreatment and undertreatment in these patients.

CCH was observed in three patients $(0.3 \%)$, which was similar to previous observations $(0.5 \%)(13)$. $\mathrm{CCH}$ is characterized by an increased quantity of C-cells within the thyroid, commonly defined as $>50$ C-cells per lowpower field in histological examination, and it has been considered as a carcinoma in situ of the thyroid parafollicular cells in hereditary $\operatorname{MTC}(29,30)$. In contrast, the clinical relevance of sporadic $\mathrm{CCH}$ outside hereditary MTC remains unclear, and the hypothetical role of $\mathrm{CCH}$ as a risk factor for sporadic C-cell malignancy is not supported by available evidence $(11,31)$.

Determination of serum hCT is more sensitive than fine-needle aspiration for MTC detection $(14,32)$. Falsenegative reports in fine-needle aspiration may occur in the case of thyroid malignancy, both in large nodules and in microcarcinomas, tumors $<10 \mathrm{~mm}$ in diameter (33). Nevertheless, fine-needle aspiration should be recommended considering the fact that one of the two MTCs in our study was $3 \mathrm{~mm}$, and could be detected positively by cytology.

The age of our patients with MTC ( 66 and 76 years) is higher than the known mean age of patients with sporadic MTC (46 years), which may be due to the mean age of the patients in our institution and may not reflect a more benign form of MTC in these patients discovered by screening (34).

Whether tumors of small size could stay potentially in their tumor stage for a very long time or may develop metastases cannot be answered, but this has to be considered. It has been shown that preoperative hCT levels correlated with the postoperative tumor size in patients with MTC, and its relationship was straighter in familial forms than in sporadic forms $(23,35)$. Both of our patients with MTC had the sporadic form, which could be an explanation for the missing correlation of hCT levels and tumor size. One patient with 20-mm tumor size without metastases could be cured by surgery, although the preoperative hCT was very high $(4.440 \mathrm{pg} / \mathrm{ml})$ with the suggested metastatic disease. But postoperative basal and pentagastrin-stimulated $\mathrm{hCT}<10 \mathrm{pg} / \mathrm{ml}$ documented the cure of this patient. The other patient with a 3-mm tumor size had lymph node metastases already and could not be cured by surgery (preoperative stimulated $\mathrm{hCT}>1.471 \mathrm{pg} / \mathrm{ml}$ ), so that the initial tumor size could not predict metastases.

In conclusion, primarily basal hCT measurement is recommended in patients with thyroid nodule disease. It has been shown that one case of MTC among 500 patients with thyroid nodule disease could be detected in an early tumor stage. Whether this high incidence of MTC has major implications or not has to be discussed, but it should be considered as a useful and recommended tool for early detection of MTC and to save the patients' life. Screening using the cost-effective hCT measurement can help in the cure of the overwhelming majority of these patients by surgery.

\section{Declaration of interest}

The authors declare that there is no conflict of interest that could be perceived as prejudicing the impartiality of the research reported.

\section{Funding}

This research did not receive any specific grant from any funding agency in the public, commercial or not-for-profit sector.

\section{References}

1 Reiners C, Wegscheider K, Schicha H, Theissen P, Vaupel R, Wrbitzky R \& Schumm-Draeger PM. Prevalence of thyroid disorders in the working population of Germany: ultrasonography screening in 96,278 unselected employees. Thyroid $2004 \mathbf{1 4}$ 926-932.

2 Raue F, Zink A \& Scherubl H. Regulation of calcitonin secretion and calcitonin gene expression. Recent Results in Cancer Research $19921251-18$.

3 Santoro M, Melillo RM, Carlomagno F, Vecchio G \& Fusco A. Minireview: RET: normal and abnormal functions. Endocrinology $20041455448-5451$.

4 Hegedus L. Clinical practice. The thyroid nodule. New England Journal of Medicine 2004351 1764-1771. 
5 Vierhapper H, Bieglmayer C, Heinze G \& Baumgartner-Parzer S. Frequency of RET proto-oncogene mutations in patients with normal and with moderately elevated pentagastrin-stimulated serum concentrations of calcitonin. Thyroid $200414580-583$.

6 Schmid KW. Thyroid gland carcinoma. Praxis 199887 367-374.

7 Dralle H, Machens A \& Lorenz K. Hereditary thyroid cancer. Chirurg 200879 1017-1028.

8 Osamura RY, Yasuda O, Kawakami T, Itoh Y, Inada K \& Kakudo K. Immunoelectron microscopic demonstration of regulated pathway for calcitonin and constitutive pathway for carcinoembryonic antigen in the same cells of human medullary carcinomas of thyroid glands. Modern Pathology 199710 7-11.

9 Reubi JC, Schaer JC \& Waser B. Cholecystokinin (CCK)-A and CCK-B/gastrin receptors in human tumors. Cancer Research 1997 $\mathbf{5 7} 1377-1386$.

10 Karges W, Dralle H, Raue F, Mann K, Reiners C, Grussendorf M, Hufner M, Niederle B \& Brabant G. Calcitonin measurement to detect medullary thyroid carcinoma in nodular goiter: German evidence-based consensus recommendation. Experimental and Clinical Endocrinology \& Diabetes 2004112 52-58.

11 Kaserer K, Scheuba C, Neuhold N, Weinhausel A, Vierhapper H \& Niederle B. Recommendations for reporting $\mathrm{C}$ cell pathology of the thyroid. Wiener Klinische Wochenschrift $2002114274-278$.

12 Rink T, Truong PN, Schroth HJ, Diener J, Zimny M \& Grunwald F. Calculation and validation of a plasma calcitonin limit for early detection of medullary thyroid carcinoma in nodular thyroid disease. Thyroid $200919327-332$.

13 Vierhapper H, Niederle B, Bieglmayer C, Kaserer K \& Baumgartner-Parzer S. Early diagnosis and curative therapy of medullary thyroid carcinoma by routine measurement of serum calcitonin in patients with thyroid disorders. Thyroid 200515 1267-1272.

14 Elisei R, Bottici V, Luchetti F, Di Coscio G, Romei C, Grasso L, Miccoli P, Iacconi P, Basolo F, Pinchera A \& Pacini F. Impact of routine measurement of serum calcitonin on the diagnosis and outcome of medullary thyroid cancer: experience in 10,864 patients with nodular thyroid disorders. Journal of Clinical Endocrinology and Metabolism 200489 163-168.

15 Papi G, Corsello SM, Cioni K, Pizzini AM, Corrado S, Carapezzi C. Fadda G, Baldini A, Carani C, Pontecorvi A \& Roti E. Value of routine measurement of serum calcitonin concentrations in patients with nodular thyroid disease: a multicenter study. Journal of Endocrinological Investigation 200629 427-437.

16 Mayr B, Brabant G \& von zur Muhlen A. Incidental detection of familial medullary thyroid carcinoma by calcitonin screening for nodular thyroid disease. European Journal of Endocrinology 1999 $141286-289$

17 Lips CJ, Hoppener JW \& Thijssen JH. Medullary thyroid carcinoma: role of genetic testing and calcitonin measurement. Annals of Clinical Biochemistry 200138 168-179.

18 Bockisch A, Brandt-Mainz K, Gorges R, Muller S, Stattaus J \& Antoch G. Diagnosis in medullary thyroid cancer with $\left[{ }^{18} \mathrm{~F}\right] \mathrm{FDG}-$ PET and improvement using a combined PET/CT scanner. Acta Medica Austriaca $20033022-25$

19 Rieu M, Lame MC, Richard A, Lissak B, Sambort B, Vuong-Ngoc P, Berrod JL \& Fombeur JP. Prevalence of sporadic medullary thyroid carcinoma: the importance of routine measurement of serum calcitonin in the diagnostic evaluation of thyroid nodules. Clinical Endocrinology $1995 \mathbf{4 2} 453-460$.

20 Costante G, Meringolo D, Durante C, Bianchi D, Nocera M, Tumino S, Crocetti U, Attard M, Maranghi M, Torlontano M \& Filetti S. Predictive value of serum calcitonin levels for preoperative diagnosis of medullary thyroid carcinoma in a cohort of 5817 consecutive patients with thyroid nodules. Journal of Clinical Endocrinology and Metabolism 200792 450-455.

21 Hahm JR, Lee MS, Min YK, Lee MK, Kim KW, Nam SJ, Yang JH \& Chung JH. Routine measurement of serum calcitonin is useful for early detection of medullary thyroid carcinoma in patients with nodular thyroid diseases. Thyroid 200111 73-80.
22 Niccoli P, Wion-Barbot N, Caron P, Henry JF, de Micco C, Saint Andre JP, Bigorgne JC, Modigliani E \& Conte-Devolx B. Interest of routine measurement of serum calcitonin: study in a large series of thyroidectomized patients. The French Medullary Study Group. Journal of Clinical Endocrinology and Metabolism $1997 \mathbf{8 2}$ 338-341.

23 Iacobone M, Niccoli-Sire P, Sebag F, De Micco C \& Henry JF. Can sporadic medullary thyroid carcinoma be biochemically predicted? Prospective analysis of 66 operated patients with elevated serum calcitonin levels. World Journal of Surgery 200226 886-890.

24 Elisei R. Routine serum calcitonin measurement in the evaluation of thyroid nodules. Best Practice \& Research. Clinical Endocrinology $\mathcal{E}$ Metabolism 200822 941-953.

25 Hodak SP \& Burman KD. The calcitonin conundrum - is it time for routine measurement of serum calcitonin in patients with thyroid nodules? Journal of Clinical Endocrinology and Metabolism 200489 511-514.

26 Dietlein M, Wieler H, Schmidt M, Schwab R, Goretzki PE \& Schicha H. Routine measurement of serum calcitonin in patients with nodular thyroid disorders? Nuklearmedizin 2008 47 65-72.

27 Doyle P, Duren C, Nerlich K, Verburg FA, Grelle I, Jahn H, Fassnacht M, Mader U, Reiners C \& Luster M. Potency and tolerance of calcitonin stimulation with high-dose calcium versus pentagastrin in normal adults. Journal of Clinical Endocrinology and Metabolism 200994 2970-2974.

28 Machens A, Hoffmann F, Sekulla C \& Dralle H. Importance of gender-specific calcitonin thresholds in screening for occult sporadic medullary thyroid cancer. Endocrine-Related Cancer 200916 1291-1298.

29 Verga U, Ferrero S, Vicentini L, Brambilla T, Cirello V, Muzza M, Beck-Peccoz P \& Fugazzola L. Histopathological and molecular studies in patients with goiter and hypercalcitoninemia: reactive or neoplastic C-cell hyperplasia? Endocrine-Related Cancer 200714 393-403.

30 Scheuba C, Kaserer K, Kotzmann H, Bieglmayer C, Niederle B \& Vierhapper H. Prevalence of C-cell hyperplasia in patients with normal basal and pentagastrin-stimulated calcitonin. Thyroid $200010413-416$.

31 Sheu SY, Gorges R \& Schmid KW. Hyperplasia of the thyroid gland. Pathology 200324 348-356.

32 Costante G, Durante C, Francis Z, Schlumberger M \& Filetti S. Determination of calcitonin levels in C-cell disease: clinical interest and potential pitfalls. Nature Clinical Practice. Endocrinology $\mathcal{E}$ Metabolism 20095 35-44.

33 Ozgen AG, Hamulu F, Bayraktar F, Yilmaz C, Tuzun M, Yetkin E, Tuncyurek M \& Kabalak T. Evaluation of routine basal serum calcitonin measurement for early diagnosis of medullary thyroid carcinoma in seven hundred seventy-three patients with nodular goiter. Thyroid 19999 579-582.

34 Saad MF, Ordonez NG, Guido JJ \& Samaan NA. The prognostic value of calcitonin immunostaining in medullary carcinoma of the thyroid. Journal of Clinical Endocrinology and Metabolism 198459 850-856.

35 Cohen R, Campos JM, Salaun C, Heshmati HM, Kraimps JL, Proye C, Sarfati E, Henry JF, Niccoli-Sire P \& Modigliani E. Preoperative calcitonin levels are predictive of tumor size and postoperative calcitonin normalization in medullary thyroid carcinoma. Groupe d'Etudes des Tumeurs a Calcitonine (GETC). Journal of Clinical Endocrinology and Metabolism $2000 \mathbf{8 5}$ 919-922.

Received 9 March 2010

Accepted 19 March 2010 